\title{
TRANSAKSI PERDAGANGAN DI WILAYAH PERBATASAN KABUPATEN SAMBAS PERSPEKTIF MASLAHẠH
}

\author{
Munadi \\ Sabri Samin \\ Kasjim Salenda \\ Kurniati \\ Institut Agama Islam Sultan Muhammad Syafiuddin Sambas \\ munadi176176@gmail.com
}

\begin{abstract}
Abstrak: Penelitian ini ingin melihat sejauhmana transaksi tersebut sesuai dengan konsepsi hukum Islam terutama teori-teori maṣlahah. Penelitian ini adalah penelitian kualitatif dengan pendekatan yuridis normatif serta teoriteori hukum Ekonomi Syariah, sehingga transaksi perdagangan di wilayah perbatasan dapat ditinjau dari kedua pendekatan teori tersebut. Hasil penelitian ini menunjukkan bahwa ada beberapa bentuk perdagangan di wilayah perbatasan di Kabupaten Sambas Kalimantan Barat diantara: Perdagangan dengan pemesanan barang, pemesanan barang ini dilakukan oleh para pembeli dari Malaysia yang memesan barang kepada pedagang Indonesia di pasar Temajuk. Mekanisme pemesanan barang ini yaitu dengan pemberian uang panjar. Sesuai dengan spesifikasi barang yang dipesan. Dalam hukum Islam dinamakan dengan ba'i salam, dan ba'i salam telah sesuai dengan aspek-aspek transaksi di sistem Muamalah.

Diantara bentuk transaksi perdagangan di wilayah perbatasan lainnya yaitu perdagangan mata uang asing atau biasa disebut dengan jual beli sarf. Perdagangan mata uang ini dilakukan antara pembeli dan penjual. Hal ini terjadi disebabkan pembeli dari Malaysia menggunakan mata uang Ringgit. Apabila pembelian tersebut terdapat sisa pengembalian maka penjual akan mengembalikannya dengan mata uang Rupiah. Oleh karena itu, disamping para pedagang tersebut menjual barang dagangannya, mereka juga sembari menjual mata uang Rupiah kepada pembeli dari Malaysia, dengan kurs yang mereka sepakati.
\end{abstract}

\section{Keywords : Wilayah Perbatasan, Salam, Șarf.}

\section{PENDAHULUAN}

Perbatasan menjadi salah satu isu yang selama ini terus menjadi masalah di Indonesia, termasuk di Kalimantan Barat. Meskipun wilayah perbatasan menjadi garda terdepan hubungan regional antara Indonesia dengan negara tetangga, faktanya wilayah perbatasan masih belum terorganisir dengan baik dan terabaikan. Contohnya, pengembangan infrastruktur maupun pembangunan sumber daya manusia. Padahal masyarakat berharap penuh pada pemerintah dengan dibentuknya kementrian khusus yang menangani wilayah perbatasan dan daerah tertinggal. Akan tetapi, implementasi pengembangan wilayah perbatasan sepertinya masih belum merata. Hasilnya, berbagai persoalan sosial keagamaan bermunculan.

Problematika yang muncul di lapangan bervariasi, mulai dari pendidikan, kesehatan, sosial keagamaan, sengketa perbatasan dengan negara tetangga yang 
berbatasan langsung dengan wilayah darat maupun wilayah laut Indonesia, masalah kesejahteraan masyarakat yang bertempat tinggal di wilayah perbatasan.

Permasalahan akan semakin kompleks mengingat berdasarkan data Kementerian Negara Pembangunan Daerah Tertinggal 2014 menunjukkan bahwa sebagian besar Kabupaten-kabupaten di wilayah perbatasan tergolong wilayah tertinggal, termasuk di dalamnya Provinsi Kalimantan Barat, Kabupaten Sambas termasuk dalam kategori tersebut. ${ }^{1}$ Padahal Kabupaten di wilayah perbatasan, termasuk pulau-pulau kecil di perbatasan, memiliki peran yang menentukan sebagai garda terdepan perekonomian bangsa Indonesia. ${ }^{2}$

Kondisi tersebut di atas kiranya menyebabkan berbagai persoalan, terutama kejahatan yang terjadi di wilayah perbatasan seperti penebangan kayu secara ilegal (illegal logging), pencurian ikan (illegal fishing), perdagangan wanita dan anak (women and child trades), dan pemasukan imigran gelap (illegal immigrants) atau illegal traffikcing in persons, dan penyelundupan baik manusia maupun barang (people, arms and explosives smuggling), serta berbagai konflik sosial dan politik yang terjadi di wilayah-wilayah perbatasan, dan lain sebagainya.

Kebahagiaan hakiki adalah kebahagiaan paripurna yang universal. Kebahagiaan abadi yang meliputi kebahagiaan jasmani dan ruhani, kebahagiaan pribadi dan masyarakat. Semua upaya dan cara untuk mencapai kepuasan itu adalah mașlahah. Mempertahankan, memelihara dan meningkatkan mutunya juga merupakan masiahah. Oleh karena itu, ajaran yang dibawa oleh nabi Muhammad saw. yang berupa syariat Islam adalah agama yang berorientasi pada kemaslahatan. Maṣlahah itu berupa rahmat, karena itu dia mendatangkan kedamaian dan kebahagiaan.

Dalam kemaslahatan tersirat di dalamnya perangkat Syariah mengatur harta dan pemeliharaan jiwa agar tetap eksis menapaki kehidupan ini. Menelusuri makna maṣlahat tidak terlepas dari pemaknaan maslahat itu sendiri yang berarti nilai manfaat yang dihasilkan atau dengan kata lain kesempurnaan manfaat dari target yang diinginkan. Dengan bahasa lain dapat dikatakan maslahat sebagai suatu usaha yang terkandung di dalamnya nilai-nilai manfaat. Hakikat mașlahah adalah manfaat itu sendiri, terlepas nilai manfaat itu sebagai out put atau nilai manfaat itu sebagai process.

Kehadiran Negara serta peran aktf pemerintah sebagai salah satu entitas pelaku ekonomi yang memiliki ciri khas sebagai perangkat hukum bagi entitas pelaku ekonomi lainnya tidak dapat dihindarkan untuk mewujudkan visi dan misi serta tujuan syariah Islam. Al-Quran hanya menyediakan prinsip-prinsip dasar dalam menuntun para pedagang dalam mewujudkan tujuan-tujuan umum dari syariah Islam tersebut (māqāsid al-Syarī'ah), yaitu mewujudkan kesejahteraan masyarakat. Terutama masyarakat perbatasan, kehadiran pemerintah dalam merealisasikan tujuan-tujuan syariah dalam lapangan kehidupan masayrakat sangat diperlukan untuk menjamin keselarasan dan keseimbangan antara transaksi perdagangan dengan maqāsid alSyari'ah.

Dalam mencapai maqāsid al-Syarì'ah, studi tentang perdagangan Islam memberi kelonggaran dalam batas-batas tertentu, untuk memilih strategi yang sesuai

\footnotetext{
${ }^{1}$ Gusmardi Bustami "Mendorong Perdagangan Lintas Batas" Warta Ekspor, Kementerian Perdagangan RI, (Agustus 2012), h. 3.

${ }^{2}$ Mustafa Abubakar, Menata Pulau-pulau Kecil Perbatasan: Belajar dari Kasus Sipadan, Ligitan dan Sebatik(Jakarta: Penerbit Buku Kompas, 2006), h. viii.
} 
dengan tahap-tahap perkembangan sosial masyarakat. Oleh karena itu apapun yang dihadapi oleh masyarakat perbatasan haruslah mengedepankan kemaslahatan terutama dalam mendapatkan barang-barang yang dimanfaatkan untuk menopang kehidupan mereka di wilayah perbatasan. Apapun dan bagaimanapun cara pemerolehan barangbarang tersebut haruslah tetap dalam koridor Syariah Islamiyah. Di satu sisi mendapatkan bahan kebutuhan masyarakat perbatasan akan berbenturan dengan Undang-undang yang berlaku dalam hal terjadi pelanggaran undang-undang, di sisi yang lain pemeliharaan jiwa dan harta dalam konsep Islam wajib di kedepankan.

Disinilah pentingnya penelitian ini dilakukan supaya sinergitas antara Undangundang dan Hukum Islam terutama konsep al-mașlaḥah al-ijtimāiyyah tidak terjadi benturan tetapi saling menutupi satu dan yang lainnya sehingga tercapai kehidupan yang lebih baik bagi masyarakat perbatasan. Penelitian ini ingin membahas tentang bentuk transaksi perdagangan di wilayah perbatasan tersebut.

\section{KAJIAN TEORETIS}

\section{A. Konsep Umum Tentang Transaksi}

Istilah perjanjian dalam hukum Indonesia disebut dengan akad. ${ }^{3}$ Didalam perdagangan istilah untuk menyatakan persetujuan antara satu pihak dengan pihak lainnya dinamakan dengan transaksi. ${ }^{4}$ Dalam terminologi hukum Islam akad juga diistilahkan dengan transaksi. Kata akad berasal dari kata al-'Aqad yang berarti mengikat menyambung, atau menghubungkan (آكَّبْطُ). Sebagai suatu istilah hukum Islam, ada beberapa definisi yang diberikan kepada akad (transaksi) diantaranya : Menurut Pasal 262 Mursyidul Khairan, akad merupakan pertemuan ijab yang diajukan oleh salah satu pihak dengan kabul dari pihak lain yang menimbulkan akibat hukum pada objek akad. ${ }^{6}$ Wabah Zuhaili mendefinisikan akad secara bahasa berarti ikatan (alrabt), perikatan, perjanjian dan permufakatan (al-ittifaq); Dalam fikih didefinisikan

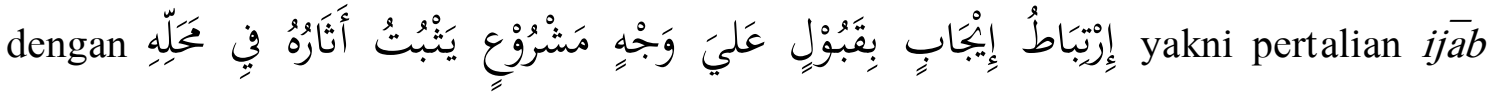
(pernyataan melakukan ikatan) dan qabūl (pernyataan penerimaan ikatan) sesuai dengan kehendak syariat yang berpengaruh pada obyek perikatan. ${ }^{7}$ Menurut Syamsul Anwar akad adalah Pertemuan ijab dan kabul sebagai pernyataan kehendak dua pihak atau lebih untuk melahirkan suatu akibat hukum pada objeknya. ${ }^{8}$

Berdasarkan beberapa definisi di atas memperlihatkan bahwa, pertama, akad merupakan keterkaitan atau pertemuan ijab dan kabul yang berakibat timbulnya hukum. Ijab adalah penawaran yang diajukan oleh salah satu pihak, dan kabul adalah jawaban persetujuan yang diberikan mitra akad sebagai tanggap terhadap penawaran

\footnotetext{
${ }^{3}$ Tim Penyusun, Kamus Bahasa Indonesia (Jakarta, Pusat Bahasa, 2008), h. 24.

${ }^{4}$ Tim Penyusun, Kamus Bahasa Indonesia, h. 1729.

${ }^{5}$ Aḥmad Abū Fatḥ, Kitāb al-Mu'āmalāt fi al-Syarī'ah al-Islamiyah wa al-Qawānīn al-Miṣriyyah, Juz 1 (Mesir : Maṭba'ahal-Busfir, 1913 M/1332 H), h. 139. Lihat juga Asy-Syaukani, Fatḥ Qädir, Juz 2 (Mesir: Musțafā al-Bāb al-Ḥalabi, 1964), h. 4.

${ }^{6}$ Muḥammad Qādir Bāsya, Mursyid al-Khairāni al-Ma'rifah al-Aḥwāl al-Insān (Kairo, Dār alFurjani, 1403 H/1983 M), h. 49.

${ }^{7}$ Wahbah al-Zuhaili, al-Fiqh al-Islām wa Adillatuhu, Juz 4 (Cet. 2; Dimasqi, 1985 M/1405 H), h. 80 .

${ }^{8}$ Syamsul Anwar, Hukum Perjanjian Islam, Studi Tentang Teori Akad Dalam Fikih Muamalah (Jakarta : PT Radja Grafindo Persada, 2010), h. 68.
} 
pihak pertama. Akad tidak terkait apabila pernyataan kehendak masing-masing pihak tidak terkait satu sama lain karena akad adalah keterkaitan kehendak kedua pihak yang tercermin dalam ijab dan kabul.

Kedua, akad merupakan tindakan hukum dua pihak karena akad adalah pertemuan ijab dan yang mempresentasikan kehendak dari satu pihak dan kabul yang menyatakan kehendak pihak lain. Tindakan hukum satu pihak, seperti janji memberi hadiah, wasiat, wakaf, atau pelepasan hak, bukanlah akad, karena tindakan-tindakan tersebut tidak merupakan isakan dua hak dan karenanya tidak memerlukan kabul. Konsepsi akad sebagai tindakan dua pihak adalah pandangan ahli-ahli hukum Islam modern. Pada zaman pra modern terdapat perbedaan pendapat. Sebagian besar fukaha memang memisahkan secara tegas kehendak sepihak dari akad, akan tetapi sebagian lain menjadikan akad meliputi juga kehendak sepihak. Bahkan ketika berbicara tentang aneka ragam akad khusus mereka tidak membedakan antara akad dan kehendak sepihak sehingga mereka membahas pelepasan hak, wasiat dan wakaf bersama-sama dengan pembahasan jual beli, sewa menyewa dan semacamnya, serta mendiskusikan apakah hibah memerlukan ijab dan kabul atau cukup ijab saja.

Ketiga, tujuan akad adalah untuk melahirkan akibat hukum. Lebih tegas lagi tuan akad adalah maksud bersama yang dituju dan yang hendak diwujudkan oleh para pihak melalui pembuatan akad. Akibat hukum akad dalam hukum Islam disebut hukum akad (hukum al-'aqd). ${ }^{9}$ Tujuan akad untuk akad bernama sudah ditentukan secara umum oleh Pembuat Hukum Syariah, sementara tujuan akad tidak bernama ditentukan oleh para pihak sendiri sesuai dengan maksud mereka menutup akad. Tujuan akad bernama dapat dikategorikan menjadi lima, yaitu :

a. Pemindahan hak milik dengan imbalan ataupun tanpa imbalan (al-tamlik).

b. Melakukan pekerjaan (al-'Amal).

c. Melakukan persekutuan (al-Isytirāk).

d. Melakukan pendelegasian (al-Tafwị̂).

e. Melakukan penjaminan (al-Tausíq) .

Pemindahan milik meliputi pemindahan atas benda dan pemindahan milik atas manfaat. Jual beli adalah akad untuk memindahkan milik atas benda dengan imbalan. Hibah adalah pemindahan milik atas benda tanpa imbalan. Pinjam pakai adalah pemindahan milik atas manfaat benda tanpa imbalan. Muzara'ah adalah akad untuk melakukan pekerjaan. Muḍarabah adalah akad untuk melakukan persekutuan modal dan usaha guna membagi hasilnya. Wakālah adalah (pemberan kuasa) adalah akad untuk melakukan pendelegasian. Kafalah (penanggungan) adalah akad untuk melakukan penjaminan.

Tercapai tujuan akad tercermin pada terciptanya akibat hukum. Bila maksud para pihak dalam akad jual beli adalah untuk melakukan pemindahan milik atas benda dari penjual kepada pembeli dengan imbalan yang diberikan oleh pembeli, maka terjadinya pemindahan milik tersebut merupakan akibat hukum akad jual beli. Akibat hukum ini, seperti ditegaskan di atas disebut dengan hukum akad. Hukum akad dibedakan menjadi dua macam, yaitu (1) hukum pokok akad (al-hukm al-Aṣl Ii al-

\footnotetext{
${ }^{9}$ Dalam peristilahan hukum Islam, kata hukum mempunyai beberapa arti. Salah satu arti hukum itu adalah akibat hukum, arti lain dari hukum adalah kualifikasi hukum. Misalnya frasa hukum jual beli bisa berarti akibat hukum jual beli, baik hukum pokok maupun akibat hukum tambahan, dan bisa juga berarti kualifikasi jual beli seperti fasid, maukuf, sah, haram dan semacamnya. Arti mana yang dimaksudkan dalam kalimat tergantung kepada konteksnya.
} 
'Aqd); dan hukum tambahan akad (al-hukm al-Tabi' Ii al-'Aqd). Hukum pokok akad adalah akibat hukum pokok yang timbul dari penutupan akad. Apabila tujuan akad dalam jual beli misalnya adalah melakukan pemindahan milik atas barang dari penjual kepada pembeli dengan imbalan dari pembeli, maka hukum pokok akad jual beli adalah terjadinya perpindahan milik atas barang yang dimaksudkan.

Hukum pokok akad sama bagi semua akad satu nama, meskipun pihak yang membuatnya berbeda-beda. Hukum pokok akad bernama sudah ditentukan oleh Pembuat Hukum Syarak sehingga tidak berbeda dari satu akad ke ada lain yang senama. Perbedaan hanya terjadi pada akad yang berbeda namanya karena berbeda tujuannya. Dengan kata lain, perbedaan tujuan dan hukum pokok akad yang hendak diwujudkan itulah yang membedakan akad bernama yang satu dengan akad bernama lain. Sedangkan di dalam akad tidak bernama tujuan itu ditentukan oleh para pihak sendiri sesuai dengan kesepakatan kehendak mereka untuk melahirkan akibat hukum pokok yang mereka inginkan.

Perealisasian hukum pokok akad, maka para pihak memikul beberapa kewajiban yang sekaligus merupakan hak pihak lain. Misalnya, dalam jual beli, penjual berkewajiban menyerahkan barang yang merupakan hak penjual. Hak dan kewajiban ini disebut hak-hak akad, dan disebut juga akibat hukum tambahan akad. Akibat hukum tambahan akad ini dibedakan menjadi dua macam, yaitu akibat hukum yang ditentukan oleh Syariah dan akibat hukum yang ditentukan oleh para pihak sendiri. Akibat hukum tambahan yang ditentukan oleh para pihak sendiri berupa klausulklausul yang mereka buat sesuai dengan kepentingannya, misalnya penyerahan barang di rumah dan diantar oleh dan atas biaya penjual.Term akad ini banyak dipergunakan dalam fiqh klasik. Secara umum dalam kitab fiqh klasik, fuqaha mendefinisikan akad dengan sesuatu yang menjadi tekad seseorang untuk melaksanakan, baik yang muncul dari satu pihak maupun yang dari dua pihak. ${ }^{10}$ Akad yang berasal dari bahasa arab ini diartikan bervariasi, secara bahasa akad digunakan dalam pengertian untuk menyatakan sesuatu yang semuanya bermuara pada terbentuknya ikatan atau penghubung terhadap dua hal. ${ }^{11}$

Kata akad ini dalam konteks Indonesia dapat diterjemahkan sebagai perjanjian, ikatan, penguatan, tapi dalam konteks hukum Islam kata akad ini menurut Syamsul Anwar adalah pertemuan $i j a b^{12}$ dan $\mathrm{kabul}^{13}$ sebagai pernyataan kehendak dua pihak atau lebih untuk yang melahirkan suatu akibat hukum pada objeknya. ${ }^{14}$ Terkadang juga kata akad ini dipergunakan dalam makna umum, yakni adanya sesuatu yang diikatkan pada orang lain untuk dirinya atau bagi orang lain yang biasanya diikuti dengan kata harus.

\footnotetext{
${ }^{10}$ Ascarya, Akad \& Produk Bank Syari'ah, (Jakarta: Raja Grafindo Persada, 2007), h. 35.

${ }^{11}$ Abdulah Muslih dan Shalah Ash-Shawi, Fikih Ekonomi Keuangan Islam, (Jakarta: Darul Haq, 2008), h. 26.

${ }^{12}$ Ijab adalah penawaran yang diajukan oleh salah satu pihak. Lihat Syamsul Anwar, Hukum Perjanjian Syariah, Studi tentang Akad dalam Fikih Muamalat, (Jakarta: Raja Garfindo, 2007), h. 69. ijab juga dapat diartikan sebagai ungkapan penyerahan barang atau penyerahan kepemilikan. Lihat juga Abdulah Muslih dan shalah Ash-Shawi Fikih Ekonomi, h. 29.

${ }_{13}$ Kabul adalah jawaban persetujuan yang diberikan mitra akad sebagai tanggapan terhadap penawaran pihak yang pertama. Syamsul Anwar, Hukum Perjanjian Syariah, h. 69. Adapun Kabul adalah tanda diterimanya kepemilikan barang atau tanda berpindahnya kepemilikan barang. Lihat. Abdulah Muslih dan shalah Ash-Shawi Fikih Ekonomi, h. 29.

14 Syamsul Anwar, Hukum Perjanjian Syariah, Studi tentang Akad dalam Fikih Muamalat, (Jakarta: Raja Garfindo, 2007), h. 68.
} 
Jika ditinjau lebih lanjut, dari beberapa definisi diatas bahwa akad akan terjadi apabila ada orang yang berkehendak melakukan akad (perjanjian, keputusan, ikatan) baik kepada dirinya sendiri maupun dengan melibatkan orang lain dalam artian bahwa terjadinya akad dapat terjadi dengan keikutsertaan orang lain dalam melakukan perbuatan serupa baik berupa pengucap maupun penerima akad tersebut.

Menurut Mahkamah Agung RI dalam Undang-undang Perbankan Syariahnya Nomor 21 tahun 2008 dituliskan bahwa akad adalah kesepakatan tertulis antara Bank Syariah atau UUS dan pihak lain yang memuat adanya hak dan kewajiban bagi masingmasing pihak sesuai dengan prinsip syariah. ${ }^{15}$ Dari pengertian ini dengan jelas dan ditegaskan bahwa akad menurut UU ini merupakan suatu akad yang tertulis. Begitu pula makna akad ini juga ditampilkan oleh Mahkamah Agung RI dalam Kompilasi Hukum Ekonomi Syari' ah (KHES) atau Hukum Perdata Islam menyatakan bahwa akad adalah kesepakatan dalam suatu perjanjian antara dua pihak atau lebih untuk melakukan dan atau tidak melakukan perbuatan hukum tertentu. ${ }^{16}$

Dari beberapa definisi yang telah ditampilkan oleh pemakalah diatas dapat dikemukakan bahwa sebenarnya kata akad yang diadopsi dari bahasa arab itu merupakan kesepakatan dua belah atau perkatan dua belah pihak pada suatu objek yang mengakibatkan adanya akibat hukum pada objek tersebut.

\section{B. Rukun dan Syarat Akad}

Seperti yang telah dijelaskan diatas bahwa akad adalah suatu perikatan antara ijab dan kabul dengan cara yang dibenarkan dalam Islam yang menetapkan adanya akibat-akibat hukum pada objeknya. Dalam hukum muamalat Islam, sebuah akad tidak terlepas dari ijab dan kabul. Ijab adalah pernyataan pihak pertama mengenai isi perikatan yang diinginkan, sedangkan kabul adalah pernyataan pihak kedua untuk menerimanya. Ijab dan kabul itu diadakan dengan maksud untuk menunjukkan adanya sukarela timbal balik terhadap perikatan yang dilakukan oleh kedua pihak yang bersangkutan.

Definisi lain tentang akad adalah segala suatu yang dikerjakan oleh seseorang berdasarkan keinginannya sendiri seperti wakaf, talak, pembebasan atau sesuatu yang pembentukannya membutuhkan keinginan dua orang seperti jual beli, perwalian, dan gadai. $^{17}$

Agar suatu akad dipandang terjadi harus diperhatikan rukun-rukun dan syaratsyaratnya. Rukun adalah unsur yang membentuk sesuatu, sehingga sesuatu itu terwujud karena adanya unsur-unsur yang membentuknya. ${ }^{18}$ Dengan kata lain rukun adalah unsur yang mutlak harus ada dalam sesuatu hal, peristiwa atau tindakan.

Menurut Syamsul Anwar ada empat rukun yang harus dipenuhi agar sebuah akad benar-benar mempunyai akibat hukum. Keempat rukun tersebut meliputi: ${ }^{19}$

a. Para pihak yang membuat akad. Syarat dari para pihak ini meliputi: (1) tamyiz dan

(2) berbilang pihak. Dapat disimpulkan bahwa Ijab dan kabul disini harus dinyatakan oleh orang yang sekurang-kurangnya telah mencapai umur tamyiz yang menyadari dan mengetahui isi perkataan yang diucapkan sehingga perkataan

${ }^{15}$ Undang-undang RI Nomor 21 Tentang Perbankan Syariah, Pasal 1 angka 13, (Jakarta: CV. Eko: 2008), h. 42.

${ }^{16}$ Mahkamah Agung Republik Indonesia 2008, Pasal 20 angka 1, hlm 8.

${ }^{17}$ Rahmat Syafi'I, Fiqih Muamalah, (Bandung: Pustaka Setia, 2001), h. 44.

${ }^{18}$ Syamsul Anwar, Hukum Perjanjian Syariah, h. 95.

${ }^{19}$ Syamsul Anwar, Hukum Perjanjian Syariah, h. 96-98. 
tersebut benar-benar menunjukkan oleh keinginan hatinya. Artinya bahwa ijab dan kabul harus dikatakan oleh orang yang cakap dalam melakukan tindakan-tindakan hukum.

b. Pernyataan kehendak para pihak. Syarat dari rukun kedua ini meliputi: (1) adanya persesuaian ijab dan kabul, (2) kesatuan majelis akad. Ijab dan kabul harus berhubungan langsung dalam majlis apabila dua belah pihak sama-sama hadir, atau sekurang-kurangnya dalam majlis diketahui ada ijab oleh pihak yang tidak hadir. Seperti misalnya ijab dinyatakan kepada pihak ketiga dalam ketidakhadiran pihak kedua. Maka, pada saat pihak ketiga menyampaikan kepada pihak kedua tentang adanya ijab itu, berarti bahwa bila pihak kedua menyatakan menerima (kabul), maka akad dipandang telah terjadi atau berlangsung.

c. Objek akad, rukun akad yang ketiga inipun mengandung syarat yang dipenuhi yaitu: (1) objek itu dapat diserahkan, (2) tertentu atau dapat ditentukan, dan (3) objek itu dapat ditransaksikan. Dapat diartikan disini bahwa semua pernyataan dari para pihak tersebut selalu berhubungan dengan objek (barang, benda) yang menjadi objek akad tersebut, disini terjadinya Ijab dan kabul harus tertuju pada satu obyek yang merupakan obyek akad.

\section{Konsep Maṣlaḥah}

Guna memahami secara benar makna mașlahah, maka perlu diperhatikan perkembangan maknanya, baik secara etimologi maupun terminologi. Adapun arti mașlahah secara etimologi mempunyai dua pengertian yang sangat berbeda. ${ }^{20}$ Pertama, mașlạhah mempunyai arti yang sama dengan manfaat baik dalam arti maupun dalam

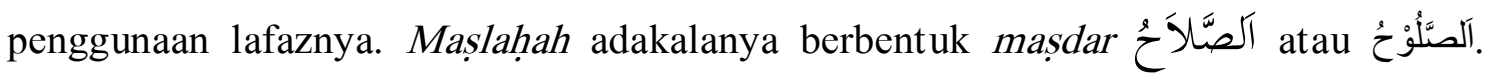

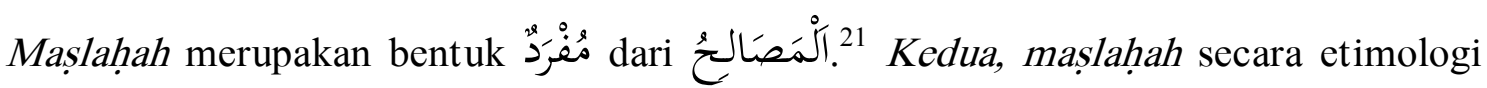
digunakan terhadap perbuatan yang mengandung kemanfaatan, dalam majaz mursal, seperti perdagangan mașlahah, mencari ilmu mașlahah. Artinya perbuatan berdagang dan mencari ilmu yang bisa mendatangkan mașlahah. ${ }^{22}$

Menurut 'Abdillah M. Husayn al-'Amiri, kata maṣlahah dari kata الصالح (kebaikan, kegunaan, validitas dan kebenaran), yang berarti bahwa sesuatu berada dalam bentuk sempurna (hay'ah kamilah) sesuai dengan tujuan atau sasaran yang

\footnotetext{
${ }^{20}$ Lihat Husein Hamid Hasan, Nazariyyah al-Maslahah fi al-fiqh al-Islami, Cairo, Dar alNahdhah al-'Arabiyyah, 1991. h. 5

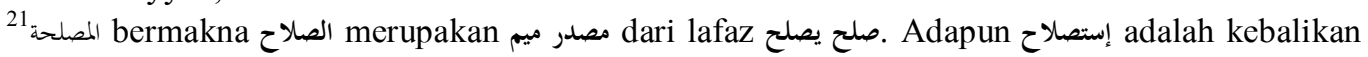
dari إستفساد. Lihat Jamaluddin Muhammad bin Maukarram al-Anshari, Lisan al-'Arab, Cairo, Dar alMisriyyah, t.t., Juz. 3, h 304. Sedangkan dalam al-Munjid disebutkan صلح يصلح berarti hilang kerusakan. Ketika dikatakan صلحت حال فلان berarti telah hilang kerusakan darinya. Lihat Louis Makluf, al-Munjid fi al-Lugah wa al-'Alam, (Beirut, Dār al-Masriq, 1986), h. 432. Sedangkan menurut al-Munjid, المصلحة, secara etimologi berasal dari bahas Arab yang dikonstruk dari 2 , . Dari empat huruf ini kemudian di konstruk, مصلحة dan صلح, صلحا, صلوحا. Kata tersebut bermakna kebaikan, adil, saleh dan jujur. Lihat Fuad Irfan, Munjid al-Tullah, (Beirut, Dār al-Fikr, t.t.), h. 479.

${ }^{22}$ Hafiny bin Nafis, Qawāid al-Lugah al-'Arabiyyah $\overline{l i}$ al-Talamiz al-Madāris al-Ś̄nawiyah, (Surabaya: al-Hidayah, t.t.), h. 124-127.
} 
dimaksud, seperti pena berada pada bentuknya yang paling tepat (șālih) ketika digunakan untuk menebas. ${ }^{23}$

$$
\text { أماالمصلحة فهي عبارة في الأصل Al-Ghazali memformulasikan definisi maslahalah }
$$

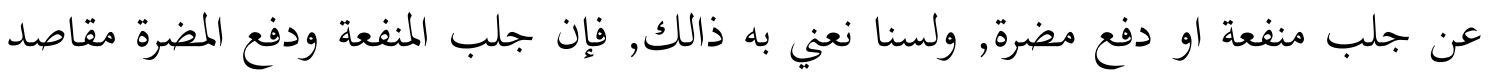

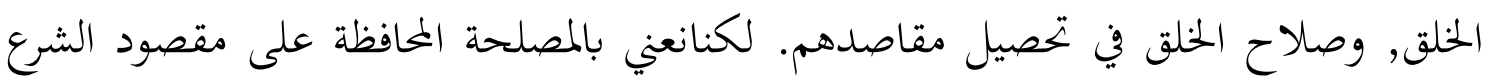

"Adapun maslahat pada dasarnya adalah ungkapan dari menarik manfaat dan menolak mudarat, tetapi bukan itu yang kami maksud; sebab menarik manfaat dan menolak mudarat adalah tujuan makhluk (manusia), dan kebaikan makhluk itu akan terwujud dengan meraih tujuan-tujuan mereka. Yang kami maksud dengan maslahat ialah memelihara tujuan syara" /hukum Islam, dan tujuan syara'mașlaḥah sebagai "upaya mengambil manfaat dan menolak kemudharatan dalam rangka memelihara tujuantujuan syara". ${ }^{24}$

Al-Ṭüi mendefinisikan mașlaḥah berdasarkan dua hal, yaitu secara 'urf dan syar'i, adapun secara 'urf adalah ${ }^{25}$ السبب المؤدي إلي صلاح و النف: adalah faktor yang membawa manfaat pada kebaikan dan manfaat. Seperti berdagang yang mendatangkan keuntungan.

Sedangkan maslaḥah menurut Syaṭi’ḅi yaitu: السبب المؤدي إلي مقصود الشارع faktor penyebab yang menghantarkan pada maksud pembuat hukum dalam masalah-masalah ibadah maupun adat (kebiasaan). Mașlahah terbagi menjadi menjadi dua: yang diuraikan oleh pembuat hukum demi dirinya sendiri, yaitu kemanfaatan makhluk-Nya dan pengaturan urusan-urusan mereka seperti adat kebiasaan itulah yang dimaksudkan oleh pembuat hukum.

Dalam sumber lain, menyebutkan bahwa dalam pandangan al-Tüfi mașlahah juga didefinisikan sebagai mengambil manfaat dan menolak bahaya. ${ }^{27}$ Adapun yang dikendaki dengan manfaat di sini menurut Imam al-Razi adalah kenikmatan dan dikehendaki dengan kerusakan adalah rasa sakit. Selanjutnya beliau mengatakan bahwa: "maslahah tidak lain kecuali kenikmatan atau segala yang menghantarkan kepadanya dan kerusakan tidak lain kecuali rasa sakit atau segala yang menghantarkan kepadanya. $^{28}$

Perlindungan terhadap kemaslahatan manusia, menurut al-Tüfi adalah tujuan utama Islam atau sumber utama tujuannya ( $q u t b$ maqșūd al-Syar'i). Perlindungan dan

\footnotetext{
${ }^{23}$ Abdillah M. Al-Husayn al-'Amiri, al-Ṭufi Feflection of Traditional Muslim Juristic Source of Law and His Views on The Priority of Regard for Human Welfare as The Highest Legal Source or Prinsciple, terj. Abdul Basir, (Jakarta: Gaya Media Pratama, 2004), h. 101.

${ }^{24}$ Abu Hamid Muhammad ibnu Muhammad al-Gazāii, al-Mustașfã min Ilm al-Usüül, Tahqiq: Hamzah Ibn Żuhairi Ḥāfize, (al-Madinah al-Munawwarah, Kulliyah al-Syarì' ah, 1997 M/1418 H), h. 481482.

${ }^{25}$ Mustafa Zayd, al- Mașlahah fî at-Tasyrî' al-Islämi Najm al-Din al-Ṭfí, edisi Kedua, (Kairo: Dar al-Fikr al-'Arabiya, 1384/1964 M), h. 54.

${ }^{26}$ Mustafa Zayd, al-Mașlahah fi at-Tasyrî' al-Islämi Najm al-Din al-Tufi, h. 55

${ }^{27}$ Abdurrahman al-Kaylāni, Qawāid al-Maqāṣid 'inda Imām Syātị̣i, Damasyq: Dār al-Fikr, 2000, h. 126 .

${ }^{28}$ Abdurrahman al-Kaylani, Qawāid al-Maqāṣid 'inda Imām Syātiḅi, h. 126.
} 
penegasan terhadapnya dalam masalah-masalah hukum, karenanya lebih didahulukan atas pertimbangan hukum lainnya. Artinya, ia memiliki prioritas atas seluruh sumber tradisional mazhab-mazhab Muslim, termasuk teks al-Quran, Sunnah atau hadis-hadis Nabi, maupun ijmak, baik dari masyarakat Muslim dan atau para ahli mazhab-mazhab hukum yang secara aktual tidak pernah terjadi dalam sejarah. ${ }^{29}$

Pandangan yang terkesan mengesampingkan eksistensi nas inilah yang bertentangan dengan ulama usul fiqh di zamannya. Menurut pandangan ulama usul ketika itu, mașlahah apapun bentuknya harus mendapat dukungan dari syarak, baik melalui nas tertentu maupun melalui makna yang terkandung oleh sejumlah nas. Pandangan al-T ūfi yang terkesan liberal ini menyebabkan ia terasing dari ulama usul fiqh di zamannya. Akan tetapi pemikirannya tentang mașlahah ini banyak dikaji dan di analisis para ulama usul fiqh sesudahnya dan banyak melahirkan doktor-doktor dalam kajian ke-Islaman.

Al-Ṭūi menjelaskan, di mana saja teks keagamaan atau ijmak, dua hal yang secara teori merupakan sumber hukum tradisional paling kuat, tidak selaras dengan kemaslahatan manusia, maka kemaslahatan manusia harus di prioritaskan dari keduanya. ${ }^{30}$ Hal ini dikarenakan kemaslahatan manusia pada dasarnya adalah tujuan dalam dirinya sendiri. Akibatnya, perlindungan terhadapnya menjadi prinsip hukum tertinggi atau sumber hukum paling kuat. ${ }^{31}$

Pandangan al-Tưufi tentang kemaslahatan manusia bertumpuh patuh pada konsepsi maqāṣid al-tasyrí ', yang menegaskan bahwa hukum di syariatkan untuk mewujudkan dan memelihara kemaslahatan manusia.

Selanjutnya al-Ṭūi menunjukkan kemaslahatan hukum atau kehidupan duniawi dapat diketahui melalui cara-cara alami yang diberikan Tuhan kepadanya, yakni oleh sifat alami dari pengalaman-pengalaman hidup manusia sendiri dan dengan tuntutan akan intelegensianya sendiri. Cara alami ini, tegas al-T.üfi merupakan metode pemahaman dan pencapaian tujuan yang paling menyakinkan. Karena itu, ia mengingatkan, maslahah seharusnya tidak digantikan oleh metode atau sumber lain yang meragukan yang mungkin bisa mengantarkan kepada kemaslahatan manusia. Sebab, sesuatu yang harus diikuti sebagai otoritas, tegas al-T üfi bukanlah kesimpulankesimpulan para ahli hukum, atau interpretasi-interpretasi mereka terhadap "teks-teks keagamaan", tetapi bukti yang kuat dari akal dan dalil-dalil yang visible ${ }^{32}$ Dengan kata lain hukum tertinggi kemaslahatan hukum atau atau kehidupan duniawi bukanlah "teks-teks keagamaan" atau kesimpulan-kesimpulan para ahli hukum tentangnya tetapi tuntutan akal dan intelegensi dalam kehidupan manusia sendiri.

Terkait dengan hal itu al-Ṭüfi menegaskan :

Tidak boleh dikatakan hukum keagamaan (sebagaimana ditetapkan oleh mazhab-mazhab hukum) lebih mengetahui kemaslahatan manusia, dan karenanya, ia seharusnya diambil dari sumber-sumbernya (sebagaimana ditetapkan oleh mereka). Sebab, kami telah menunjukkan bahwa perlindungan terhadap kemaslahatan manusia merupakan salah satu dari prinsip hukum

\footnotetext{
${ }^{29}$ Mustafa Zayd, al-Mașlahah fí al-Tasyrī' al-Islāmi Najm al-Din al-Ṭ̂̄î̀, h. 6.

${ }^{30}$ Mustafa Zayd, al- Mașlaḥah fì al-Tasyrì' al-Islāmi Najm al-Din al-Ṭ̂üî, h. 6.

${ }^{31}$ Mustafa Zayd, al- Mașlaḥah fì al-Tasyrì' al-Islāmi Najm al-Din al-Ṭ̂üî, h. 6.

${ }^{32}$ Mustafa Zayd, al- Mașlahah fì al-Tasyri' al-Islāmi Najm al-Din al-Ṭūî̀, h. 43.
} 
agama (teks-teks agama). Ia merupakan prinsip yang paling kuat dan khas. Oleh karena itu, memberikan prioritas kepadanya untuk mencapai kemaslahatan. ${ }^{33}$

Tidak seperti kemaslahatan hukum dan kehidupan duniawi manusia, al-Țūfi mempersilahkan kemaslahatan keagamaan dan masalah-masalah ibadah diputuskan atau dibimbing oleh teks agama.

Gagasan maslahah al-Ṭufi tidak dipadukan dalam kitab usul fiqh secara khusus. Gagasannya lahir ketika al-Ṭüfi memberikan syah terhadap hadis no 3234 dalam kitab Arbai'in Nawawi mahakarya Yahya Ibn Syarifuddin al-Nawawi. Dari pembahasan ini kemudian melahirkan sebuah gagasan yang boleh dikatakan liberal radikal sehingga tidak berlebihan kalau ada ulama ușul yang menulis tentangnya yang menilai bahwa alT.ūfi adalah sosok yang jarang dijumpai bahkan belum ada yang pernah mengajukannya dari kalangan pemikir sebelumnya ataupun semasanya.

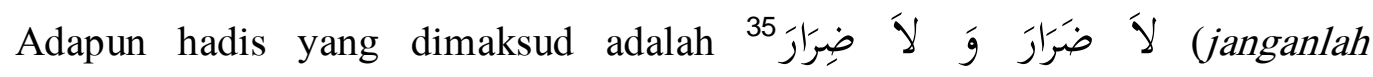
menyebabkan bahaya atau kerugian pada orang lain dan jangan membalas suatu kerugian dengan kerugian lainnya). Hadis ini oleh al-Țüfi dijadikan sebagai bukti (argumen) tekstual atas eksistensi mașlahah. Dengan demikian bisa dimengerti bahwa hadis di atas sekaligus dijadikan sebagai paradigma dari gaya berpikir al-Ṭufi baik dari dataran teoritik maupun aplikasinya.

Dalam membangun proyek mașlahah-nya al-Tūüi bersandar pada empat prinsip utama. Masing-masing prinsip merupakan kerangka utama yang dijadikan al-Tûufi sebagai pijakan pikiran epistimologinya. Keempat prinsip utama tersebut adalah: ${ }^{36}$

$$
\text { 1. إستقلال العقول بإدراك المصالح و المفاسد }
$$

Kemandirian pikiran dengan menyadari adanya Kebaikan dan kerusakan

Prinsip ini mengutarakan bahwa akal manusia secara independen dapat menemukan mașlahah dan mafsadah. Namun demikian indenpedensi rasio dalam menemukan maslahah bukanlah pada semua bidang termasuk ibadah, al-Tüufi membatasi pada bidang Muamalat serta adat kebiasaan. Prinsip ini mengedepankan pada peran rasio ini jelas berbeda dibandingkan dengan para usuliyyun yang lain yang mengakui maslahah sebagai sumber hukum setelah ditunjukkan oleh hukum serta terjustifikasi oleh naș.

${ }^{33}$ Abdillah M. Al-Husayn al-'Amiri, al-Thufi Feflection of Traditional Muslim Juristic Source of Law and His Views On The Priority of Regard for Human Welfare as The Highest Legal Source or Prinsciple, h. 43.

${ }^{34}$ Mustafa Zayd, al- Mașlahah fì al-Tasyrì al-Islämi Najm al-Din al-Ṭ̂üî, h. 113.

${ }^{35}$ Hadis di atas diriwayatkan oleh Abu Sa'id Ibn Malik Ibn Sinan al-Khudri ra. Adapun kualitas hadis diatas adalah hasan yang diriwayatkan dengan mata rantai periwayatan ( sanad) yang lengkap oleh Ibn Majah, al-Dār al-quṭni, dan yang lainnya, namun tanpa menyebutkan perawi pertamanya (mursal) oleh Imām Mālik Ibn Anas dalam Muwatta', dari 'Amir Ibn Yahya dari ayahnya, dari Nabi, dengan tidak menyebut nama 'Abu Sa'id Ibn Malik Ibn Sinan al-Khudri ra. ada sejumlah jalur periwayatan lain yang masing-masing saling menguatkan. Lihat al-Imām al-Malik, Muwatta', Juz II (Mesir, Dār Ihyā al-Turas al-'Arabi, t.t.), h. 754. Abu Abdullah Muhammad bin Yazid, Sunan Ibnu Majah, Juz 2 (Beirut: Dar alFikr, tt), h. 784. Hadis no. 2340.

${ }^{36}$ Mustafa Zayd, al- Mașlaḥah fì al-Tasyrì' al-Islāmi Najm al-Din al-Ṭüfì, h. 127-132. Asas-asas di atas juga dikutip oleh Saifuddin Zuhri dalam disertasinya Maslahah dan Implikasinya Sebagai Sumber Hukum Islam: Kajian Tentang Konsep Naj al-Din al-Țfí (Ringksan Disertasi tidak diterbitkan). (Yogyakarta, UIN Sunan Kalijaga, 2008), h. 5. dan juga dikutip oleh Munawir Sadzali sebagai pemuja al-Ṭufi dalam bukunya, Kontektualisasi Ajaran-Ajaran Islam (Jakarta: Temprint, 1995), h. 287, juga Nasrun Harun mengutip dalam Bukunya Ushul Fiqh I, (Jakarta: Logos Wacana Ilmu, 1997), h. 1126. 


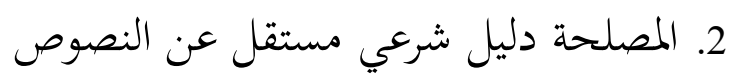

Maṣlahah merupakan dalil syar'i sah yang terlepas dari teks.

Prinsip ini sebagai kelanjutan dari prinsip di atas, dari ungkapan ini bisa dimengerti bahwa dalam pandangan at-Thufi, maslahah merupakan dalil syar'i yang independen. Dalam pengertian mașlaḥah al-Ṭūfi tidak memiliki ketergantungan kepada kesaksian atau konfirmasi naș.

$$
\text { 3. بجل العمل بالمصلحة هو المعاملات و العادات دون العبادات }
$$

Objek Pembahasan Maṣlaḥah adalah Bidang Muamalat dan 'adat (kebiasaan) tidak termasuk bidang Ibadah.

Maslahah sebagai dalil syar'i objek garapannya adalah terbatas pada bidang muamalah dan 'adah. Dengan demikian mașlahah menurut al-Tüfi tidak bisa menjamah pada bidang ritual (ibadah). Dalam bidang ibadah menurut al-Ṭüfi yang berhak hanyalah Allah Swt semata. Di sini akal tidak punya wewenang. Dengan kata lain akal hanya meneruskan aspek kelestarian dari ibadah itu sendiri. Sedangkan aspek perubahan itu ada pada wilayah muamalah dan adat. Hal ini tersusun dengan ungkapan al-Tuufi yang menyatakan sebagai haqqu al-musyari. Artinya bagi al-T.ūfi akal manusia tidak sanggup untuk menembus rahasia mașlahah dibalik ibadah.

$$
\text { 4. المصلحة أقوي أدلة الشرع }
$$

Maṣlahahah merupakan dalil syar'i yang paling kuat.

Al-Tüfi mengakui ada sembilan belas dalil yang bisa dijadikan sebagai metode istimbat hukum. Namun dalam kacamata al-Tūfi yang paling kuat dari yang sembilan belas itu adalah nas dan ijmak. Namun ketika terjadi pertentangan antara mașlahah dengan nas dan ijmak, maka jalan yang ditempuh al-Ṭüfi adalah memenangkan mașlahah. Dari kenyataan semacam ini bisa dipahami bahwa sebagai dalil hukum tidak saja fungsional ketika nas dan ijmak tidak meng-corfirm-nya. Namun juga fungsional ketika nas dan ijmak terjadi pertentangan. Hal ini mengindikasikan bahwa al-Țüfi sangat mementingkan mașlahah dibandingkan dengan dalil yang lain. Dalam keadaan seperti itu, Husein Hamid Hasan berkesimpulan bahwa maṣlaḥah bagi al-Ṭüfi merupakan dalil syar'i yang paling kuat secara mutlak. ${ }^{37}$

Nampaknya penilaian Husein Hasan Hamid tersebut tidak berlebihan mengingat mașlahah merupakan tujuan dalam legislasi hukum Islam. Sedangkan nas dan ijmak merupakan sarana untuk mencapai tujuan tersebut. Sehingga kalau terjadi pertentangan antara dan nas dan ijmak di satu sisi dengan mașlaḥah di sisi yang lain, maka maslahah harus diutamakan karena tujuan lebih utama daripada sarana. Sedangkan nas dan ijmak tidak lebih dari sarana mencapai tujuan itu sendiri yaitu kemaslahatan. Alasan ini nampaknya bersesuaian dengan apa yang diungkapkan alTuufi "karena mașlaḥah merupakan tujuan dari seorang mukallaf dalam menetapkan hukum, maka mengesampingkan dalil sebagai sarana atas mașlahah (sebagai tujuan) menjadi urgen karena tujuan harus didahulukan dari pada sarana.

Kecenderungan al-Ṭúfi untuk memprioritaskan mașlahah dibandingkan dengan dalil-dalil yang sangat kentara. Dengan demikian bisa di analisis bahwa maṣlahah di

\footnotetext{
${ }^{37}$ Husein Hamid Hasan, Nazariyyah al-Mașlạhah fĩ al-Fiqh al-Islāmy (Kairo: Dar al-Nahdhah al'Arabiyyah, 1991), h. 535.
} 
sini adalah berperan sebagai substansi hukum itu sendiri. Sedangkan nas dan ijmak serta dalil yang lain berperan sebagai sarana untuk mencapai substansi itu sendiri.

Pijakan epistemologi al-Ṭûfi di atas memiliki keunikan tersendiri dibandingkan dengan dalil yang lain. Sebagai contoh misalnya dengan al-Syatibi yang memang sejak awal mengembangkan mașlahah-nya dengan model istiqräi maknawi-nya serta maqashid al-Syariah-nya. Adapun al-Gazali yang menjadikan mașlahah-nya masih sangat kental dalam bingkai syar'i. Namun al-T ûfi di sini memiliki sisi yang berbeda secara diametral ketika membicarakan sandaran epistimologinya mengingat dalam menetapkan hukum Islam keterlibatan akal dalam menetapkan hukum dalam pemikiran al-Ṭüfi mendapatkan porsinya secara signifikan.

Relevansinya mașlahah al-Ṭüfi terhadap perdagangan yang sesuai dengan syariah sebenarnya dapat dilihat pada pijakan epistemologi yang nomor tiga dijadikan sebagai fondasi bangunan mega proyek mașlahahnya yang sudah dengan jelas dikatakan : بحل العمل بالمصلحة و العادات دون العبادات prinsip ini menghendaki bahwa ladang garapan mașlahah al-Ṭüfi sebagai instrumen atau metode operasionalisasi adalah hanya bidang muamalat (termasuk di dalamnya perdagangan) bukan masalahmasalah ibadah. Dalam masalah ibadah al-Ṭ̂ufi mempersilahkan teks agama untuk membimbingnya.

Eksistensi al-Mașlahah dalam perdagangan dalam konteks ke-Indonesian terlihat dengan jelas pada asas-asas dalam melakukan perjanjian. Dalam Hukum kontrak Syariah terdapat beberapa asas yang harus melandasinya, adapun asas-asas tersebut adalah asas al-Mașlahah. Dengan asas kemaslahatan dimaksudkan bahwa akad yang dibuat oleh para pihak bertujuan untuk mewujudkan kemaslahatan bagi mereka dan tidak menimbulkan kerugian atau memberatkan. Apabila dalam pelaksanaan akad terjadi suatu perubahan keadaan yang tidak dapat diketahui sebelumnya serta membawa kerugian yang fatal bagi pihak bersangkutan sehingga memberatkannya, maka kewajibannya dapat diubah dan disesuaikan kepada batas yang masuk akal. ${ }^{38}$

Untuk melihat bagaimana sigfinikansi al-Mașlahah sebagai instrumen dalam rangka menetapkan hukum perdagangan, maka mengetahui kaidah-kaidah fikih sebagai medianya menjadi penting. Di antara kaidah fikih yang berbunyi الضرر يزال kaidah ini bertujuan untuk menyelesaikan maqāṣid Syariah dengan menolak mafsadah atau setidaknya meringankannya. Sehingga tidak heran jika Ahmad al-Nadwi menyebutkan bahwa penerapan kaidah di atas meliputi lapangan luas di dalam fikih bahkan bisa jadi meliputi seluruh materi fikih yang ada. ${ }^{39}$

Contoh yang bisa diajukan dalam masalah ini adalah larangan dalam bisnis Syariah melakukan penimbunan barang-barang kebutuhan pokok masyarakat karena perdagangan dalam Islam memandang bahwa perbuatan tersebut dapat mengakibatkan kemudharatan bagi rakyat. Dalam pelarangan tersebut terdapat maslahah bagi masyarakat karena penolakan mudarat ataupun penarikan manfaat tujuan utamanya untuk meraih kemaslahatan dibalik keduanya. Namun terhadap contoh ini bisa di ajukan pertanyaan bagaimana dengan penimbunan yang dilakukan Bulog. Penting untuk diketahui bahwa penimbunan oleh Bulog dalam rangka untuk menjaga kestabilan harga dan menjamin ketersediaan bahan makanan pokok, seperti beras,

\footnotetext{
${ }^{38}$ Samsul Anwar, Hukum Perjanjian Syariah : Studi Tentang Akad Dalam Muamalat, h. 90.

${ }^{39}$ Ahmad al-Nadwī, al-Qawāid al-Fiqhiyyah (Beirut: Dār al-Qalam, 1420 H/2000 M), h. 287.
} 
penumpukan dan penyimpanan beras oleh Bulog dapat dibenarkan bahkan diharuskan sekalipun bertentangan dengan bunyi hadis "tidak boleh menahan harta kecuali orang aniaya". Inilah aplikasi penjelasan al-Ṭufi bahwa di mana saja teks keagamaan atau ijmak dua hal yang secara teori merupakan sumber hukum tradisional paling kuat-tidak selaras dengan kemaslahatan manusia, maka kemaslahatan manusia harus di prioritaskan dari keduanya (teks keagamaan dan ijmak).

Berangkat dari sekelumit bangunan formulasi mașlahah baik dari sisi etimologi maupun terminologi prespective tersebut, dapat di bangun atau konklusi pemahaman bahwa maslahah yang merupakan instrumen atau metode operasionalisasi ijtihad dapat dicerna sebagai sebuah penetapan hukum terhadap suatu kasus yang sama sekali sepi dan sunyi dari ketetapan nas dan atas pertimbangan kepentingan hidup manusia yang berujung pada penarikan manfaat dan menghilangkan kemudharatan.

Muhammad Ayub dalam bukunya Understanding Islamic Finance, memaparkan bahwa secara keseluruhan tujuan di balik syariat Allah swt. adalah kebahagian dan kesejahteraan manusia di dunia dan akherat, dan semua hal yang menjamin kesejahteraan dan memenuhi kepentingan utama dari umat manusia tercakup dalam tujuan-tujuan syariah (maqasid al-syari ${ }^{6}$ ah) Tujuan-tujuan tersebut dapat dibagi dalam dua kelompok, yaitu : ${ }^{41}$

a. Tujuan Primer yang ingin diwujudkan oleh syariah adalah perlindungan dan pemeliharaan atas:

1) Agama.

2) Kehidupan.

3) Keturunan - anggota keluarga.

4) Harta.

5) Intelek.

6) Kehormatan.

b. Tujuan Sekunder

Tujuan primer syariah akan membawa ke beberapa tujuan sekunder yang terdiri atas :

1) Penegakan keadilan dan kesamaan dalam masyarakat.

2) Peningkatan keamanan sosial, sikap saling membantu, dan solidaritas, khususnya untuk membantu yang miskin serta membutuhkan dalam memenuhi kebutuhan dasar mereka.

3) Pemeliharaan kedamaian dan keamanan.

4) Peningkatan kerjasama dalam hal kebaikan dan larangan perbuatan serta tindakan jahat.

5) Peningkatan nilai moral universal yang utama dan semua tindakan yang perlu untuk pemeliharaan dan penguasaan alam.

Zakaria al-Subri dalam kitabnya Masādir al-Ahkām al-Islamiyyah yang memberikan syarat-syarat lain sebagai berikut, antara lain: ${ }^{42}$

a. Hendakya kemaslahatan itu bersifat hakiki bukan bersifat imajinatif dalam arti apabila orang yang berkesempatan dan yang memusatkan perhatian pada itu yakin

${ }^{40}$ Abū Husain Muslim bin al-Hajjaj, Șahih Muslim, Kitāb al-Buyū' Bāb Tahrìm al-Iḥtikār fî̀ alAmwāl, Juz 2 (Mesir: Isa al-Bāb al-Ḥalabi wa Syurakah, t.th.), h. 702.

${ }^{41}$ Muhammad Ayyub, Understanding Islamic Finance (Wiley \& Sons Ltd. England, 2007), h. $23-25$.

${ }^{42}$ Zakaria al-Subri, Mas̄adir al-Ahkam Islamiyyah (Mesir: al-Qāhirah, 1975), h 102. 
bahwa membina hukum berdasarkan kemaslahatan tersebut akan dapat menarik manfaat dan menolak madarat bagi umat manusia.

b. Kemaslahatan itu hendaknya bersifat universal dan tidak parsial. Sebagai contoh ialah apa yang dikemukakan oleh al-Gazali yaitu: kalau dalam suatu pertempuran melawan orang kafir mereka membentengi diri dan membuat pertahanan melalui beberapa orang muslim yang tertawan, sedang orang kafir tersebut dikwatirkan akan melancarkan agresi dan dapat menghancurkan kaum muslimin mayoritas maka pennyerangan terhadap mereka harus dilakukan, meskipun akan mengakibatkan kematian beberapa orang muslimin yang sebenarnya harus dilindungi keselamatan jiwanya.

c. Hendaknya kemaslahatan itu bukan kemaslahatan yang mulgha (yang jelas di tolak oleh nas).

\section{METODOLOGI PENELITIAN}

Penelitian ini merupakan penelitian kualitatif terhadap bentuk transaksi perdagangan di wilayah perbatasan Indonesia dan Malaysia khususnya Kabupaten Sambas, tepatnya di wilayah Kecamatan Paloh dan Kecamatan Aruk Kabupaten Sambas, kemudian transaksi perdagangan lintas batas orang dan barang tersebut akan di analisa berdasarkan hukum Islam dan perundang-undangan yang berlaku. Penelitian ini dinamakan penelitian terpadu yaitu antara penelitian lapangan (field research) dan penelitian literatur (library research). Lokasi penelitian yakni di Kecamatan Paloh tepatnya di desa Temajuk dan desa Aruk di Kecamatan Sajingan Kecil Kabupaten Sambas Provinsi Kalimantan Barat. Kecamatan Paloh, salah satu Kecamatan dari 14 Kecamatan yang secara administratif berada di wilayah Kabupaten Sambas, yaitu salah satu daerah perbatasan negara Indonesia dengan Malaysia (Serawak). Pilihan pada lokasi di Kecamatan Paloh Kabupaten Sambas selain karena spesifik daerah perbatasan sebagai daerah prioritas untuk dibangun, juga spesifik budaya masyarakatnya karena mayoritas suku Melayu beragama Islam. Penelitian ini menggunakan pendekatan interdisipliner, yaitu pendekatan yuridis normatif, pendekatan hukum Islam, dan pendekatan hukum ekonomi Syariah. Sumber data primer dalam penelitian ini berupa bentuk dan praktik transaksi perdagangan di wilayah perbatasan Indonesian dan Malaysia di Kabupaten Sambas Propinsi Kalimantan Barat yang dilakukan oleh mereka yang melakukan transaksi perdagangan di wilayah perbatasan yang mencakup Pedagang lintas batas yang dilakukan oleh masyarakat di daerah perbatasan, Pelaku bisnis lintas batas negara (Pedagang besar yang mempunyai gudang penyimpanan barang-barang dari Malaysia), Tokoh masyarakat dan tokoh agama yang jadi panutan masyarakat, Kepala Badan pengelolaan perbatasan sekretariatan Pemerintah Daerah Kabupaten Sambas, dan Kepala Imigrasi Kelas II Sambas. Sedangkan data sekunder berupa dokumen laporan dan kebijakan yang dibuat oleh pemerintah daerah kebijakan pemerintah pusat tentang perbatasan.

Proses pengumpulan data penelitian ini menggunakan metode wawancara terbuka, metode observasi, metode dokumentasi. Pada penelitian ini, peneliti mengambil data menggunakan instrumen pedoman wawancara, lembar observasi dan tabel dokumentasi yang sewaktu-waktu dapat berubah di lapangan. Proses pengumpulan data, reduksi data, dan penyajian data serta penarikan kesimpulan adalah bagian dari analisis data. Teknik pemeriksaan keabsahan data yang digunakan dalam penelitian ini hanya menggunakan tiga teknik, meliputi: 1) Perpanjangan Keikutsertaan; 2) Ketekunan Pengamatan ; dan 3) Triangulasi. 


\section{HASIL PENELITIAN DAN PEMBAHASAN}

\section{A. Perdagangan dengan sistem Pemesanan}

Jual beli merupakan sebuah aktivitas yang dilakukan oleh setiap manusia untuk mendapatkan barang, atau manfaat yang ingin diambil dari sebuah objek jual beli. Untuk mendapatkan sebuah barang yang diinginkan, terkadang kita langsung mendapatkannya tanpa harus menunggu dengan waktu yang lama. Namun tidak jarang kita harus menunggu dalam waktu yang cukup lama. Proses ini biasanya untuk mendapatkan barang yang sesuai dengan keinginan kita. Sistem pesanan merupakan salah satu bentuk jual beli yang sering kita gunakan dalam kehidupan sehari-hari.

Kebutuhan masyarakat Malaysia yang begitu kompleks, membuat para pedagang harus mencari sebuah alternatif sistem dagang. Barang-barang yang mereka jual ada sebagian yang disimpan di gudang sebagai stok barang. Ketika ada konsumen yang menginginkan sebuah barang dengan jumlah banyak, dan harus sesuai dengan keinginan konsumen, maka pedagang akan mengambilkan stok yang ada di gudang. Praktik dagang di pasar batas selain menerapkan sistem jual beli langsung, mereka terkadang menerapkan sistem pesanan terhadap barang yang dipesan oleh konsumennya, baik yang berasal dari sekitar pasar maupun dari Sambas.

Kondisi pasar yang tidak setiap hari beroperasi, melainkan tiga kali seminggu, yakni hari Selasa, Kamis, dan Sabtu membuat pasar batas selalu ramai dikunjungi oleh para pembeli yang sebagian besar berasal dari Malaysia. Dengan terbatasnya hari operasional pasar, maka masyarakat Sambas yang berbelanja di pasar batas terkadang melakukan pemesanan barang yang dibutuhkan kepada para pedagang di pasar tersebut. Pemesanan barang yang dilakukan oleh warga Malaysia bervariasi, dimulai dari bahan pokok, hingga keperluan perlengkapan bangunan.

Berdasarkan observasi yang dilakukan peneliti, para pedagang ada juga yang menerapkan sistem pesanan dengan sistem deposit (panjar) dan pembayaran langsung diawal kepada para konsumennya. Sistem pesanan ini dilakukan kepada masyarakat Malaysia yang berbelanja di pasar perbatasan Temajuk. Sistem pesanan yang dilakukan kepada masyarakat Malaysia lebih banyak dilakukan, mengingat hampir seluruh pembeli adalah warga masyarakat Malaysia.

Berdasarkan hasil observasi yang dilakukan oleh peneliti di lapangan yang berkaitan dengan praktik jual beli pesanan telah diperkuat dengan hasil wawancara bersama beberapa informan. Seperti yang disampikan oleh H. Sulaiman dan Eka pedagang sembako dan pedagang aksesoris handphone ketika diwawancarai oleh peneliti.

Kalau ada pesanannya biasa kita sediakan, kalau sudah ada pesanan baru kita terima uangnya dan dia ambil barangnya. Karena pengalaman ini dek saya dulu kasih pinjam juga, tapi begitu tutup susah taginya, dulu kan ada to langganan saya, ambil di sini suatu waktu dia tutup dia tidak datang lagi. Dan sekarang sistemnya ndak bisa pinjam lagi. Kendalanya kan kalau tutup, orang sebelah yang punya utang ndak bisa bayar ke kita lagi. Kadang dia belanja dengan Sped Boat melalui Hamadi. Jadi sekarang tu, saya kasih barangnya kalau ada uangnya. ${ }^{43}$

Sistem pesanan dilakukan apabila telah ada pesanan barang dari konsumen. Barang yang sudah disediakan harus diambil, selain itu juga ada pedagang yang

\footnotetext{
${ }^{43}$ H. Sulaiman, Pedagang, wawancara, 13 April 2018, Temajuk, Sambas.
} 
menerapkan deposit (panjar) terhadap barang yang dipesan oleh konsumennya. Seperti yang diungkapkan oleh salah seorang pedagang yang menerapkan deposit ketika diwawancarai oleh peneliti.

Kalau di sini kita biasa melayani penjulan barang dengan jual beli langsung dan melalui order (Pesanan), untuk order kita menerapkan deposit kepada orang yang mau beli. ${ }^{44}$

Dalam praktiknya berdasarkan pengamatan peneliti, pedagang di pasar batas apabila menerapkan sistem pesanan, maka mereka akan menerima pembayaran terlebih terdahulu kemudian barang yang dipesan akan diambil oleh pemesan. Sedangkan cara lain, yaitu dengan menerapkan sistem deposit diawal untuk menjaga keseriusan pemesan terhadap barang yang akan dibeli. Dalam sistem deposit, pedagang menerima pembayaran baik dalam bentuk mata uang Rupiah maupun Ringgitsebagai sistem pembayaran.

Berdasarkan hasil penelitian, para pedagang ada yang menerapkan sistem pesanan terhadap barang yang diperdagangkan. Praktik yang dilakukan ada yang menerapkan sistem deposit dan juga membayar terlebih dahulu. Hal ini dilakukan apabila ada pembeli yang memerlukan barang dalam jumlah banyak. Sistem yang digunakan adalah dengan menggunakan uang muka (deposit) sebagai bentuk kesepakatan.

Pembayaran yang dilakukan dapat menggunakan dua jenis mata uang, yakni mata uang Rupiah dan Ringgit. Apabila Ringgitmengalami kenaikan atau penurunan kurs, maka pedagang akan menyesuaikan dengan harga Ringgityang dikurs kan ke mata uang Rupiah tanpa merubah harga.

Dalam konsep jual beli sering kita mendengar istilah (order) atau pembelian barang dengan sistem pemesanan terlebih dahulu. Sistem pemesanan barang ini biasa dilakukan karena pembeli ingin memiliki suatu barang yang sesuai dengan kehendaknya, akan tetapi produsen belum menyediakan dan harus membuat atau menyediakan sesuai dengan pesanan konsumen. Sistem pesanan menjadi salah satu alternatif untuk memenuhi kebutuhan konsumen.

Dalam konsep Islam terdapat model praktik dagang seperti ini yang biasa disebut dengan praktik Salam dan Istishna". Keduanya merupakan bentuk akad jual beli dengan menggunakan sistem pemesanan terlebih dahulu. Akad Salam dan Istishna" memiliki perbedaan pada waktu penyerahan uang sebagai tanda kesepakatan. Apabila pembayaran sebagai tanda kesepakatan dilakukan diawal waktu, maka termasuk dalam kategori akad Salam, namun jika pembayaran itu diakhirkan setelah menerima barang maka termasuk kategori akad Istishna".

Dalam penelitian yang dilakukan oleh peneliti, para pedagang di pasar perbatasan Temajuk ada yang menerapkan jual beli dengan sistem pemesanan atau biasa disebut dengan order, dengan menerapkan deposit (panjar) dan menerapkan pembayaran langsung diawal waktu.

Praktik dengan menyerahkan uang diawal waktu sebagai tanda kesepakatan dilakukan untuk menjaga keseriusan konsumen dengan akad yang telah disepakati. Selain itu juga, ada pedagang yang menyediakan barangnya terlebih dahulu kemudian menerima pembayaran diakhir waktu pengambilan.

\footnotetext{
${ }^{44}$ Eka, Pedagang, wawancara, 13 April 2018, Temajuk, Sambas.
} 
Khusus untuk memenuhi barang terlebih dahulu, para pedagang menerapkannya kepada para pelanggan yang sudah lama dikenalnya, mengingat beberapa pedagang memiliki pengalaman buruk terkait akad pemesanan ini.

Harga menjadi salah satu syarat dari pelaksanaan praktik jual beli salam. Harga yang ditawarkan harus diketahui jumlahnya, jenis alat tukarnya misalnya, Rupiah, Dollar, Ringgit, dan lain sebagainya. Alat tukar yang digunakan merupakan alat tukar yang sah dan diakui oleh kedua belah pihak, dan yang terakhir penyerahan uang dilakukan pada waktu akad berlangsung. Selain itu juga, barang yang diperjual belikan menjadi salah satu syarat agar dapat terpenuhinya praktik jual beli salam. Persyaratan yang harus diketahui adalah barang yang dipesan harus diketahui oleh kedua belah pihak baik sifatnya, ukurannya, hitungannya, serta takarannya.

Jelas batas waktu dan tempat penyerahan barang tersebut, barang yang dipesan merupakan tanggungan penjual kepada pembeli, dan tidak ada khiyār Syarat bagi kedua belah pihak. Untuk harga yang ditawarkan penjual kepada pembeli menggunakan harga ukuran Rupiah, namun mengingat sebagian besar pembeli adalah masyarakat Malaysia, penjual dapat menerima pembayaran dengan menggunakan mata uang Ringgityang disesuaikan dengan nilai Rupiah.

Dalam praktiknya pedagang yang menerapkan praktik jual beli pesanan (salam) ini bermacam-macam. Peneliti mencoba untuk menggali beberapa informasi dari pedagang diantaranya pedagang souvenir dan pedagang sembako. Khusus praktik pemberian deposit, hal ini masuk dalam kategori jual beli menggunakan uang panjar atau biasa disebut dengan ba'i al-'urbun. Dalam konsep jual beli salam, uang yang diserahkan merupakan pembayaran yang telah disepakati dan diserahkan terlebih dahulu dengan maksud untuk menjaga akad salam tersebut. Selain itu juga menjadi modal untuk biaya produksi.

Berdasarkan hasil kajian analisis tentang praktik dagang dengan sistem pesanan (ba'i al-salam), terdapat dua sistem yaitu, pembayaran dilakukan diawal waktu, serta adanya penerapan deposit atau panjar (ba'i al-'urbun). Pembayaran diwaktu awal mendekati konsep jual beli salam, sedangkan penerapan deposit merupakan sebuah bentuk praktik jual beli yang berbeda dengan praktik jual beli salam.

\section{B. Jasa Penukaran Uang}

Mengingat posisi pasar batas Temajuk yang berada di perbatasan antarnegara, yaitu Indonesia-Malaysia dan pengunjung pasar lebih banyak berasal dari Malaysia, maka alat tukar yang digunakan untuk melakukan transaksi terdiri dari dua mata uang, yaitu mata uang Rupiah dan mata uang Ringgit. Hal ini sudah menjadi kebiasaan di pasar batas Temajuk, mengingat belum ada jasa penukaran uang resmi yang didirikan oleh pemerintah. Sehingga peluang ini dimanfaatkan oleh beberapa pedagang untuk membuka jasa penukaran uang Ringgit, baik penukaran uang Ringgitke Rupiah ataupun sebaliknya.

Berdasarkan hasil observasi peneliti di lapangan, ketersediaan fasilitas penunjang seperti money changer belum tersedia, sehingga banyak timbul money changer tidak resmi. Secara tidak langsung peneliti melihat proses tukar menukar yang dilakukan oleh pedagang. Seperti yang diungkapkan oleh H. Sulaiman salah seorang pedagang di pasar batas Temajuk kepada peneliti di tempat dagangannya.

Ibu, bagaimana..? (Tanya Pak Sulaiman) mau tukar, 100 Ringgit. (Konsumen). Mari sudah, ada tapi 400.000 ribu saja. Mari sudah. (Pak Sulaiman) Jadi 
langsung dek, kalau ada rupiah baru kita menukar. Begitupun kalau kita ada Ringgit baru kita menukar juga. ${ }^{45}$

Dari hasil wawancara di atas, salah satu pedagang yang berdagang sembako di pasar batas Temajuk melakukan aktivitas penukaran jenis mata uang Ringgityang ditukarkan ke mata uang Rupiah. Hal ini dilakukan untuk memberi kemudahan bagi konsumen yang tidak memiliki uang Rupiah atau Ringgit, atau bahkan hanya sekedar menukar uang untuk keperluan koleksi, seperti yang dilakukan oleh peneliti pada saat menukar Rupiah dengan mata uang Ringgit.

Berdasarkan hasil observasi peneliti di lapangan, proses yang dilakukan dalam melakukan aktivitas penukaran mata uang asing oleh pedagang, para pedagang akan membeli dibawah harga pedagang lain, setelah itu akan ditukarkan atau dijual kembali ke penukar yang lain dengan tawaran di atas harga beli Ringgit tadi. Disinilah orang yang menukarkan Ringgitharus teliti untuk mencari penukar Ringgityang mau menukarkan (membeli) Ringgitnya dengan harga yang tinggi. Seperti yang diungkapkan oleh H. Sulaiman, penukar mata uang Ringgitdi pasar Temajuk ketika diwawancarai oleh peneliti.

Bisa juga dek, tergantung kalau ada orang yang punya Rupiah atau Ringgit biasanya dia lari ke kita tukar. Kadang ada orang tukar saya beli, kalau saya beli tadi begitu Rp. 400.000, bisa jual Rp. 420.000. misalnya saya tahu penukaran dia tukar 41 atau 42, ya saya beli Rp. 4.000. uang ini tidak bisa kita pakai, harus jual kembali. ${ }^{46}$

Kegiatan penukaran uang yang dilakukan oleh para pedagang bukan merupakan mata pencaharian utama. Dikarenakan profesi mereka hanya berdagang, baik berdagang sembako, baju, makanan, Dan lain sebagainya. Penukaran dilakukan apabila pedagang memiliki Ringgitatau Rupiah untuk ditukarkan kembali. Apabila tidak tersedia uang Rupiah atau Ringgit, maka mereka akan menukarkan ditempat lain yang juga antar sesama pedagang. Sebab mata uang Ringgit tidak dapat digunakan di luar pasar batas Temajuk-Kuching. Informan lain yang juga menerima jasa penukaran mata uang asing, yaitu Arman. Arman berprofesi sebagai pedagang kebutuhan sandang seperti baju, celana, kaos, dan souvenir. Aktivitas penukaran yang dilakukan merupakan usaha sampingan selain berdagang kebutuhan sandang.

Seperti yang diungkapakan oleh Arman ketika diwawancarai oleh peneliti.

Saya juga biasa terima tukar Ringgitatau rupiah. kalau ada teman-teman pedagang yang butuh rupiah, ya mereka tukar sama saya. Saya tidak pergi ambil di tempat mereka, karena saya juga harus jaga kios pak. Jadi, mereka yang datang ke saya. Kalau mereka tukar ya langsung kita kasih uangnya Ringgitatau rupiah. Kadang juga saya bawa turun ke kota untuk tukar di penukaran uang di Jakarta. ${ }^{4}$

Dengan adanya para pedagang yang menawarkan jasa penukaran atau jual beli mata uang asing, sangat membantu pedagang lainnya untuk mendapatkan uang Rupiah, dikarenakan mata uang Ringgityang diperoleh tidak dapat digunakan untuk melakukan transaksi jual beli di Jakarta. Oleh karena itu, harus segera ditukarkan dengan mata

\footnotetext{
${ }^{45}$ H. Sulaiman, Pedagang, wawancara, 13 April 2018, Temajuk, Sambas

${ }^{46}$ H. Sulaiman, Pedagang, wawancara, 13 April 2018, Temajuk, Sambas.

${ }^{47}$ Arman, Pedagang, Wawancara, 13 April 2018, Temajuk, Sambas.
} 
uang Rupiah. Himbauan tentang penukaran mata uang Ringgitjuga telah disampaikan oleh kepala bidang Perdagangan luar negeri Dinas Perindustrian dan Perdagangan Pemda. Sambas kepada seluruh pedagang di pasar perbatasan Temajuk-Kuching. Seperti yang disampaikan oleh bapak Herman.

Kami mendesak pedagang di sana jangan menahan uang Ringgit itu sampai 1 bulan. 2 minggu sekali atau seminggu sekali harus segera tukar. Kalau kita tahan sebulan, bank di Sambas Nugini kosong dengan uang Ringgit. Pernah terjadi sampai 4 (empat) kali, karena uangnya semua tertahan pedagang perbatasan. ${ }^{48}$

Berdasarkan hasil observasi yang dilakukan oleh peneliti dan pengalaman menukarkan uang Ringgit serta hasil wawancara yang dilakukan dengan beberapa informan, para pedagang valas berjualan Ringgitdengan secara langsung bertemu dengan masyarakat atau pedagang yang ingin menukarkan Ringgitnya dengan Rupiah. Transaksi dilakukan ditempat dengan kesepakatan yang telah disepakati. Misanya pada saat peneliti melakukan wawancara, peneliti mendapati seorang warga Malaysia yang menukarkan uang Ringgitsebesar 100 Ringgit. Uang tersebut ditukarkan kepada Haji Sulaiman dengan jumlah Rp. 400.000, dan dilakukan secara langsung. Dari transaksi ini, pembeli Ringgit akan menukarkan kembali di money changer yang ada di Kabupaten Sambas.

Banyaknya Para pedagang yang menawarkan jasa penukaran mata uang Ringgit (pedagang valuta asing) yang belum terdaftar secara resmi di Bank Indonesia perwakilan Prov. Kalbar, hal ini yang menjadikan pilihan utama para pedagang untuk menjual atau menukarkan uang Ringgitnya kepada pedagang valas, tanpa harus jauh turun ke Kabupaten Sambas untuk menukarkan uang Ringgitmereka.

Berdasarkan hasil penelitian peneliti di lapangan terdapat dua jenis mata uang yang digunakan, yakni mata uang Rupiah dan mata uang Ringgit(Malaysia). Adanya peredaran mata uang Ringgitdi wilayah perbatasan Indonesia- Malaysia membuat tumbuh subur praktik penukaran atau jual beli mata uang asing di pasar perbatasan. Hal inilah yang menimbulkan banyak bermunculan money changer yang tidak resmi didirikan dan dikelola oleh pedagang pasar perbatasan. Mereka mampu melihat peluang dari adanya transaksi penukaran atau jual beli mata uang asing tersebut.

Praktik yang dilakukan oleh para pedagang yang menerima penukaran uang Ringgitdilakukan secara langsung bertemu dengan pihak yang menukarkan, dilakukan dalam waktu yang bersamaan, dan ada keuntungan yang diambil. Pemerintah Pemda Sambas melalui Dinas Perindustrian dan Perdagangan Pemda Sambas diharapkan segera membangun money changer resmi yang dari atau yang ditunjuk oleh Bank Indonesia. Keberadaan money changer sangatlah penting untuk mendukung proses penukaran mata uang asing yang resmi, dan memperlancara aktivitas perdagangan di kawasan perbatasan.

Dalam setiap transaksi perdagangan yang dilakukan oleh masyarakat membutuhkan sebuah ukuran nilai tukar yang biasa disebut dengan uang. Uang telah menjadi satuan alat tukar untuk mencapai kata sepakat dalam bertransaksi. setiap negara tentunya memiliki mata uang yang sah sebagai alat tukar yang telah disepakati, hal ini juga yang dimiliki oleh Indonesia dengan mata uang yang diakui, yaitu Rupiah (Rp) dan negara Malaysia dengan mata Ringgit. Ketika seseorang akan bepergian ke

\footnotetext{
${ }^{48}$ Heman, Pedagang, wawancar, 13 April 2018, Temajuk, Sambas.
} 
luar negeri tentunya ia akan menukarkan sejumlah uangnya untuk dapat dijadikan sebagai alat transaksi yang diakui oleh sebuah negara. Penukaran ini biasa dilakukan pada money changer dan foreign exchange.

Dalam konsep Islam praktik dagang menukarkan pecahan uang yang sama atau menukarkan uang yang berbeda (perdagangan valas) dikenal dengan istilah al-sharf. AlȘarf menurut Wahbah al-Zuhaily di dalam Rozlinda, secara bahasa berarti al-ziyādah (tambahan), penukaran, atau transaksi jual beli. Sedangkan menurut istilah al-sarf adalah jual beli uang dengan uang, baik yang sejenis atau berbeda jenis. Islam membolehkan jenis transaksi ini dengan ketentuan yang telah ditetapkan oleh syariat Islam. Terkait dengan praktik ini, yaitu apabila uang yang ditukarkan sama nilai nominalnya dan sama jenisnya, maka tidak diperkenankan adanya kelebihan atau pengurangan. Sedangkan apabila uang yang ditukarkan berbeda jenisnya (Rupiah dan Dollar), maka diperbolekan mengambil keuntungan selama bukan untuk berspekulasi (untung-untungan), dan harus diserahkan secara tunai (over the counter). ${ }^{49} \mathrm{Hal}$ ini telah disampaikan oleh Rasulullah SAW di dalam hadisnya.

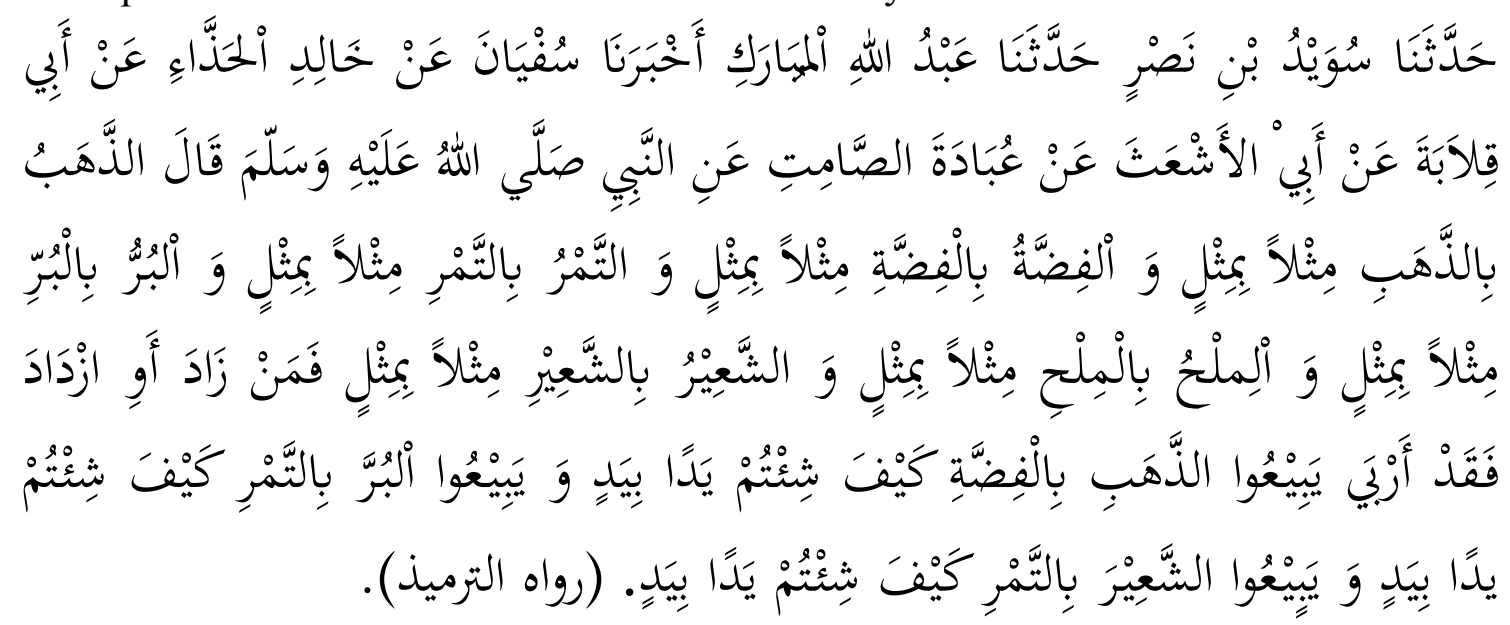

Artinya:

Suwaid bin Nașr telah menceritakan kepada kami, Abdullah bin al-Mubarak telah menceritakan kepada kami, Sufyan telah mengabarkan kepada kami dari Khalid alḤazāi dari Abu Qilābah dari Abu al-Asy'as dari 'Ubādah bin al-Ṣamit dari Nabi saw., beliau bersabda: "Emas (ditukar) dengan emas sama ukuran berat timbanganya, perak (ditukar) dengan perak sama berat timbangannya dan kurma (ditukar) dengan kurma sama berat takarannya, burr (gandum) dengan burr (gandum) sama berat takarannya, garam dengan garam sama berat timbangannya, sya'ir (gandum) dengan sya'ir (gandum) sama berat timbangannya. Barangsiapa menambah atau meminta tambahan sungguh ia telah melakukan riba. Juallah emas dengan perak sesuka hatimu secara tunai dan jualah sya'ir (gandum) dengan kurma sesuka hatimu secara tunai."

Dalam penelitian yang dilakukan oleh peneliti pada pasar perbatasan TemajukKuching, alat tukar yang digunakan adalah mata uang Rupiah dan mata uang Malaysia, yaitu Ringgit. Namun letak pasar yang berada di Indonesia tidak.

Hal ini telah membuat mata uang Ringgit menjadi dominan di pasar tersebut. Hal ini disebabkan karena sebagian besar pengunjung pasar merupakan masyarakat 109.

${ }^{49}$ Rozalinda, Fiqh Ekonomi Syariah Prinsip dan Implementasinya Pada Sektor Keuangan, h. 
Malaysia yang berbelanja dengan menggunakan uang Ringgitsehingga banyak praktik pertukaran uang asing yang tidak resmi dijalankan oleh para pedagang. Berbeda halnya dengan money changer yang berada di wilayah Kabupaten Sambas yang telah mendapatkan izin dari Bank Indonesia dan sesuai dengan kurs yang dikeluarkan oleh Bank Indonesia.

Praktik yang dilakukan oleh para pedagang yang menerima penukaran mata uang Ringgit-Rupiah atau Rupiah-Ringgit di pasar perbatasan Temajuk secara tidak langsung telah menyerupai model transaksi Spot. Transaksi Spot merupakan transaksi perdagangan valas yang dilakukan secara tunai. Hal ini yang diterapkan oleh para pedagang dalam melakukan aktivitas penukaran mata uang Ringgit dan Rupiah. Para pedagang mengambil keuntungan dari transaksi ini berkisar Rp.100-Rp.500/1 Ringgityang ditukarkan dan penyerahan dilakukan pada saat itu ditempat transaksi.

Transaksi valas dengan jenis transaksi Spot, yaitu transaksi penukaran mata uang asing, dimana penerima maupun yang menyerahkan berada dalam suatu tempat secara bersamaan untuk menyerahkan dan menerima objek yang ditukar. Transaksi jenis ini sangat dianjurkan karena dapat diserah terimakan secara langsung dan terbebas dari unsur garar. Transaksi spot memiliki banyak jenis penyerahan dana, diantaranya Value Today, yaitu penyerahan yang dilakukan pada tanggal yang sama dengan tanggal dilakukannya transaksi. Kedua, Value Tomorrow yaitu penyerahan dilakukan pada hari kerja berikutnya. Ketiga, Value Spot yaitu penyerahan dilakukan dua hari kerja setelah tanggal transaksi. ${ }^{50}$

Para pedagang dalam menyerahkan dana atau uang sebagai objek pertukaran atau jual beli dilakukan pada hari itu juga, tanpa ada jeda waktu. Hal ini dilakukan agar Ringgit yang didapat, dapat segera digantikan dengan mata uang Rupiah sehingga dapat digunakan.

Praktik ini dilakukan apabila para pedagang memiliki jumlah uang Rupiah yang cukup untuk ditukarkan dengan Ringgit, apabila pedagang tidak memiliki ketersediaan uang Rupiah, maka pedagang akan menukarkan pada money changer yang berada di wilayah Kabupaten Sambas.

Berdasarkan hasil kajian analisis tentang praktik jual beli atau penukaran mata uang asing (ba'i al-sarf) yang dilakukan oleh para pedagang di pasar perbatasan Temajuk-Kuching, para pedagang melakukan transaksi penukaran atau jual beli jenis mata uang yang berbeda (Rupiah-Ringgit) yang dilakukan ditempat (on the spot) dengan mengambil keuntungan dari praktik tersebut.

\section{PENUTUP}

Berdasarkan kajian teori dan lapangan tersebut, dapat disimpulkan bahwa ada beberapa bentuk perdagangan di wilayah perbatasan di Kabupaten Sambas Kalimantan Barat diantara: Perdagangan dengan pemesanan barang, pemesanan barang ini dilakukan oleh para pembeli dari Malaysia yang memesan barang kepada pedagang Indonesia di pasar Temajuk. Mekanisme pemesanan barang ini yaitu dengan pemberian uang panjar. Sesuai dengan spesifikasi barang yang dipesan. Dalam hukum Islam dinamakan dengan ba'i salam, dan ba'i salam telah sesuai dengan aspek-aspek transaksi di sistem Muamalah.

\footnotetext{
${ }^{50}$ Rozalinda, Fiqh Ekonomi Syariah Prinsip dan Implementasinya Pada Sektor Keuangan, h.
} 113. 
Diantara bentuk transaksi perdagangan di wilayah perbatasan lainnya yaitu perdagangan mata uang asing atau biasa disebut dengan jual beli sarf. Perdagangan mata uang ini dilakukan antara pembeli dan penjual. Hal ini terjadi disebabkan pembeli dari Malaysia menggunakan mata uang Ringgit. Apabila pembelian tersebut terdapat sisa pengembalian maka penjual akan mengembalikannya dengan mata uang Rupiah. Oleh karena itu, disamping para pedagang tersebut menjual barang dagangannya, mereka juga sembari menjual mata uang Rupiah kepada pembeli dari Malaysia, dengan kurs yang mereka sepakati.

\section{DAFTAR PUSTAKA}

Abubakar, Mustafa, Menata Pulau-pulau Kecil Perbatasan: Belajar dari Kasus Sipadan, Ligitan dan Sebatik Jakarta: Penerbit Buku Kompas, 2006).

Amiri, Abdillah M. al-Husayn al-‘, al-T Tufi Feflection of Traditional Muslim Juristic Source of Law and His Views on The Priority of Regard for Human Welfare as The Highest Legal Source or Prinsciple, terj. Abdul Basir, Jakarta: Gaya Media Pratama, 2004.

Anshari, Jamaluddin Muhammad bin Maukarram al-, Lisan al-'Arab, Cairo, Dar alMisriyyah, t.t., Juz. 3.

Anwar, Syamsul, Hukum Perjanjian Islam, Studi Tentang Teori Akad Dalam Fikih Muamalah Jakarta : PT Radja Grafindo Persada, 2010.

Ascarya, Akad \& Produk Bank Syari'ah, Jakarta: Raja Grafindo Persada, 2007.

Ayyub, Muhammad, Understanding Islamic Finance Wiley \& Sons Ltd. England, 2007.

Bāsya, Muḥammad Qādir, Mursyid al-Khairāni al-Ma’rifah al-Aḥwāl al-Insān, Kairo, Dār al-Furjani, 1403 H/1983 M.

Bustami, Gusmardi "Mendorong Perdagangan Lintas Batas"Warta Ekspor, Kementerian Perdagangan RI, Agustus 2012.

Fath, Ahmad Abū., Kitāb al-Mu'āmalāt fi al-Syarī'ah al-Islamiyah wa al-Qawānīn alMișriyyah, Juz 1 Mesir : Maṭba'ahal-Busfir, 1913 M/1332 H.

Gazāli, Abu Hamid Muhammad ibnu Muhammad al-', al-Mustasfā min Ilm al-Usūul, Tahqiq: Hamzah Ibn Żuhairi Hậfiz, al-Madinah al-Munawwarah, Kulliyah alSyari' ah, $1997 \mathrm{M} / 1418 \mathrm{H}$.

Hajjaj, Abū Husain Muslim bin al-, Sahih Muslim, Kitāb al-Buyū' Bāb Tahrìm alIhtikār fí al-Amwāl, Juz 2 (Mesir: Isa al-Bāb al-Ḥalabi wa Syurakah, t.th.

Harun, Nasrun Ushul Fiqh I, Jakarta: Logos Wacana Ilmu, 1997.

Hasan, Husein Hamid, Nazariyyah al-Maṣlaḥah fī al-Fiqh al-Islāmy Kairo: Dar alNahdhah al-'Arabiyyah, 1991.

Hasan, Husein Hamid, Nazariyyah al-Maslahah fi al-fiqh al-Islami, Cairo, Dar alNahdhah al-'Arabiyyah, 1991. 
Irfan, Fuad, Munjid al-Tullah, Beirut, Dār al-Fikr, t.t.

Kaylāini, Abdurrahman al-, Qawāid al-Maqāṣid 'inda Imām Syātiḅi, Damasyq: Dār alFikr, 2000.

Mahkamah Agung Republik Indonesia 2008, Pasal 20 angka 1.

Makluf, Louis, al-Munjid fî al-Lugah wa al- 'Alam, Beirut, Dār al-Masriq, 1986.

Malik, al-Imām al-, Muwatta’, Juz II Mesir, Dār Ihyā al-Turas al-‘Arabi, t.t.

Muslih, Abdulah dan Shalah Ash-Shawi, Fikih Ekonomi Keuangan Islam, Jakarta: Darul Haq, 2008.

Nadwi, Ạ̣mad al-̄, al-Qawāid al-Fiqhiyyah, Beirut: Dār al-Qalam, 1420 H/2000 M

Nafis, Hafiny bin, Qawāid al-Lugah al-'Arabiyyah $\overline{l i}$ al-Talamiż al-Madāris alSänawiyah, Surabaya: al-Hidayah, t.t.

Subri, Zakaria al-, Mas̄adir al-Ahkam Islamiyyah, Mesir: al-Qāhirah, 1975.

Syadzali Munawir Kontektualisasi Ajaran-Ajaran Islam Jakarta: Temprint, 1995.

Syafi'i, Rahmat, Fiqih Muamalah, Bandung: Pustaka Setia, 2001.

Syaukani, al-, Fatḥ Qādir, Juz II, Mesir: Musțafā al-Bāb al-Ḥalabi, 1964.

Tim Penyusun, Kamus Bahasa Indonesia, Jakarta, Pusat Bahasa, 2008

Undang-undang RI Nomor 21 Tentang Perbankan Syariah, Pasal 1 angka 13, Jakarta: CV. Eko: 2008.

Yazid, Abu Abdullah Muhammad bin, Sunan Ibnu Majah, Juz II, Beirut: Dar al-Fikr, tt

Zayd, Mustafa, al- Mașlahah fī at-Tasyrì' al-Islāmi Najm al-Din al-Ṭufi, edisi Kedua, Kairo: Dar al-Fikr al-'Arabiya, 1384/1964 M.

Zuhaili, Wahbah al-, al-Fiqh al-Islām wa Adillatuhu, Juz IV, Cet. II; Dimasqi, 1985 $\mathrm{M} / 1405 \mathrm{H}$.

Zuhri, Saifuddin, Maslahah dan Implikasinya Sebagai Sumber Hukum Islam: Kajian Tentang Konsep Naj al-Din al-Tufí, "Ringksan Disertasi tidak diterbitkan". Yogyakarta, UIN Sunan Kalijaga, 2008.

\section{Sumber Wawancara:}

H. Sulaiman, Pedagang, Wawancara, 13 April 2018, Temajuk, Sambas.

Eka, Pedagang, Wawancara, 13 April 2018, Temajuk, Sambas.

H. Sulaiman, Pedagang, Wawancara, 13 April 2018, Temajuk, Sambas

H. Sulaiman, Pedagang, Wawancara, 13 April 2018, Temajuk, Sambas.

Arman, Pedagang, Wawancara, 13 April 2018, Temajuk, Sambas.

Heman, Pedagang, Wawancar, 13 April 2018, Temajuk, Sambas. 